\title{
FENOMENOLOGI RAMADANOMIC DI NEGERI JUNJUNGAN BENGKALIS
}

\author{
Saiful Bahri \\ Sekolah Tinggi Ilmu Ekonomi (STIE) Syariah Bengkalis \\ Email: saifulbahri.usa@gmail.com
}

\begin{abstract}
ABSTRAK
Allah SWT. tidak hanya memberi tugas kepada manusia sebagai khalifah di muka bumi melainkan juga melengkapi kebutuhan manusia itu sendiri dalam bentuk limpahan rezeki. Kesempurnaan nikmat itu telah Allah SWT. gariskan sebelum Rasulullah SAW. wafat, itu lah wahyu terakhir. Kesempurnaan nikmat itu begitu melimpah turun di bulan suci Ramadhan. Geliat ekonomi sangat jelas terlihat bahkan sebelum bulan suci itu tiba. Dialah Ar-Rahman Ar-Rahim dan Khairur Raziqin yang mencurahkan rezeki-Nya kepada bumi pertiwi dan khususnya Negeri Junjungan Bengkalis. Fenomena ekonomi di bulan suci itu pada akhirnya dikenal dengan istilah Ramadanomic yang menjadi kajian kali ini. Dengan menggunakan metode analisis deskriptif, kajian sederhana ini diharapkan memberi pencerahan meskipun hanya seperti "setetes embun pagi".
\end{abstract}

Kata kunci: Rezeki, Mekanisme Pasar, Kebahagiaan.

\section{PENDAHULUAN}

Kekayaan alam yang melimpah serta tanah yang subur menjadikan Kabupaten Bengkalis sebagai elemen bangsa yang makin hari makin dikenal masyarakat luas. Masyarakatnya pun terkenal dengan masyarakat religius. Hal itu merupakan manifestasi dari "adat bersendikan syara' dan syara' bersendikan Kitabullah". Meskipun sehari-hari mereka terlupa dengan istilah tersebut, namun realisasi dalam hal pewarisan nilai-nilai agamis terstruktur sedemikian rupa sejak dulu kala.

Islam, agama inilah yang menjadi "way of life" masyarakat Kabupaten Bengkalis turun-temurun. Dengan tujuan menabur rahmat bagi seluruh alam (rahmatan lil 'alamin), syari'at agama Islam terus lestari dan membumi di Negeri Junjungan ini.

Keberkahan dari langit dan bumi terbuka karena keimanan masyarakat Kabupaten Bengkalis. Terbukti limpahan keberkahan itu berkesinambungan tanpa henti. Hal itu sesuai dengan firman Allah SWT. yang bermaksud: "Dan seandainya penduduk suatu negeri beriman kepada Allah niscaya akan kami buka pintu keberkahan dari langit dan bumi..." (QS. Al-a'raf [7]: 96)

Maka, tampaklah seperti yang disaksikan sekarang, limpahan rezeki, tingkat kebahagiaan masyarakat Kabupaten Bengkalis yang semakin hari, makin cerah, cemerlang, gemilang, dan terbilang. Terlebih fenomena itu terjadi pada bulan suci Ramadhan, di mana keberkahan itu dilipatgandakan oleh Allah SWT.

Bahkan, limpahan rahmat itu sudah tampak sebelum Ramadhan tiba. Menjamurnya masyarakat yang menyelenggarakan kenduri (walimah) sebagai 
bukti kemapanan ekonomi mereka, selain sebagai wujud ketinggian sifat berbagi mereka kepada sesama. Akhirnya, keberkahan itu terus mengalir dengan deras.

Dalam tatanan ekonomi, dengan limpahan rezeki masyarakat Kabupaten Bengkalis, secara tidak langsung menggenjot demand mereka, yang pada gilirannya membuat harga di pasaran melejit naik. Fenomena itu sama sekali tidak membuat daya beli mereka surut. Karena, yang mereka inginkan hanyalah kebahagiaan (happiness), meskipun harus merogoh saku agak dalam.

Seperti cita-cita pemerintah negeri Bhutan pada beberapa dekade terakhir, yang ingin mewujudkan Gross National Happiness (GNH) sebagai tujuan nasional, bukan seperti negara lain yang menjadikan Gross National Product (GNP) sebagai barometer ekonomi negara.

Kebahagiaanlah yang menjadi ukuran, bukan materi. Buat apa punya harta banyak, tapi tidak bahagia, apalagi harta yang tidak berkah. Sebaliknya, biarlah punya harta apa adanya tetapi selalu merasakan kebahagiaan. Bukankah materialisme merupakan warisan Kapitalistik?

Kapitalisme yang menanamkan nilai-nilai materialistik dalam perekonomian global, sehingga dunia gelap mata terhadap norma dan susila yang diwariskan peradaban sejak dulu kala. Bagi pengikut Kapitalis, dengan melimpahnya harta yang mereka punya juga berarti menyimpan kebahagiaan yang tinggi. Padahal, pada hakikatnya, mereka juga mengetahui bahwa harta bukanlah segala-galanya.

Kajian ini bermaksud untuk mendeskripsi fenomena ekonomi pada bulan Ramadhan yang disebut dengan Ramadanomic. Sengaja Bengkalis dijadikan sebagai tempat pengamatan, karena penulis berdomisili di Negeri Junjungan itu sendiri. Dengan demikian, diharapkan kajian ini menempati nilai objektivitasnya tersendiri.

Ramadanomic merupakan gabungan dari kata Ramadhan dan ekonomi (Ramadan and economic). Secara harfiah berarti ekonomi Ramadhan, atau ekonomi bulan Ramadhan. Karena menjadi bulan spesial dan fenomenal, maka bulan ini berdampak pada ekonomi secara khusus, selain, sejatinya juga berpengaruh terhadap segala lini kehidupan.

Melimpahnya rezeki, faktor permintaan dan penawaran, naiknya harga di pasaran yang terangkum dalam kajian mekanisme pasar, serta memuncaknya tingkat kebahagiaan sehingga misery index (indeks kesengsaraan) bisa dikatakan nihil menjadikan kajian ini diharapkan lebih spesifik. Secara teoritis berbagai variabel tersebut di atas merupakan manifestasi dari beberapa teori yang dipaparkan berikut.

\section{DASAR TEORI}

Allah SWT. adalah pemberi rezeki yang paling pemurah. Sesuai dengan do'a Nabi Musa 'alaihissalam, yang termaktub dalam al-Qur'an Surah al-Ma idah [5]: 114 yang bermaksud: “...dan berilah kami rezeki, sesungguhnya Engkaulah pemberi rezeki yang paling baik."

Selain itu, rezeki yang dikaruniakan oleh Allah SWT. telah sempurna bersamaan dengan sempurnanya agama Islam itu sendiri. Firman Allah SWT. dalam al-Qur'an Surah al-Ma`idah ayat 3 bahwa, "Pada hari ini Kusempurnakan 
bagi kalian agama kalian, dan juga Kusempurnakan bagi kalian nikmat-Ku, dan aku ridha Islam sebagai agama kalian".

Sementara, rezeki bagi orang yang bertakwa menempati posisi tersendiri, sesuai dengan firman Allah SWT. dalam QS. Ath-Thalaq [65]: ayat 2 yang bermaksud: "...Dan, siapa yang bertakwa kepada allah, maka Dia akan memberinya jalan keluar (dari suatu masalah), serta memberinya rezeki dari sumber yang tiada ia sangka...".

Manusia adalah khalifah (wakil) Allah SWT. di muka bumi. Manusia telah dibekali dengan semua karakteristik mental dan spiritual serta materi untuk memungkinkan hidup dan mengemban misinya secara efektif. (Mardani 2015, 20)

Ciri utama sistem ekonomi Islam adalah konsep bahwa Allah SWT., Tuhan Penguasa alam Semesta dan Maha Pemberi. Allah SWT. memberi nafkah dan penghidupan bagi semua makhluk-Nya di seluruh alam. Allah SWT. juga yang telah menciptakan semua harta dan sumber-sumber yang dengannyalah manusia memperoleh nafkah. Sejatinya, Allah SWT. berkomitmen untuk memberi makan, menjaga dan memelihara seluruh makhluk, termasuk manusia. Allah SWT. yang meluaskan dan menyempitkan rezeki. (Chaudry 2012, 2)

Di antara sekian banyak fungsi harta antara lain adalah sebagai berikut (Suhendi 2005, 27): untuk menyempurnakan pelaksanaan ibadah yang khas (mahdhah); meningkatkan keimanan dan ketakawan kepada Allah SWT; untuk menyambung hidup; untuk menyelaraskan kehidupan dunia-akhirat; untuk mengembangkan dan menegakkan ilmu pengetahuan; untuk memutar perananperanan kehidupan; dan terakhir untuk menumbuhkan silaturahim.

Tentang mekanisme pasar, dapat disimak pada penjelasan (Karim 2014, 2) sebagai berikut: Dalam ekonomi konvensional kita tidak akan pernah menemukan bagaimana perilaku seorang konsumen apabila ia memasukkan unsur pelarangan bunga dan kewajiban untuk mengeluarkan zakat dalam setiap pengambilan keputusannya. Karena pelarangan bunga dan kewajiban membayar zakat adalah sebuah bentuk tatanan syariah yang tidak semua orang menganutnya. Maka, pembahasan perilaku konsumsi dalam ekonomi konvensional hanya memperhatikan perubahan-perubahan pada variabel ekonomi saja seperti harga dan pendapatan. Dalam kenyataannya, banyak kondisi objektif terjadi, tidak mampu dijelaskan secara akurat dalam ekonomi konvensional dan karena memang tidak dijelaskan.

Lebih lanjut ia mengemukakan beberapa pertanyaan sebagai berikut: Mengapa seorang individu rela mengeluarkan pendapatannya untuk kepentingan sosial seperti membantu orang yang terkena musibah? Mengapa tingkat konsumsi berbeda antara musim lebaran dan bukan musim lebaran? Mengapa negara masih memberlakukan monopoli pada beberapa jenis industri? Mengapa suku bunga dianggap sebagai riba, dan mengapa revenue sharing atau profit sharing diperbolehkan dalam Islam? Jelas semua pertanyaan ini tidak menjadi perhatian dalam mikro ekonomi konvensional. Tetapi tetap menjadi perhatian dalam kajian ekonomi Islam.

Jika yang disinggung di atas adalah musim lebaran, maka kajian ini tentang konsumsi dan demand atau mekanisme pasar pada bulan Ramadhan. Karena, di Bengkalis, upaya masyarakat membeli kebutuhan untuk lebaran terjadi pada bulan Ramadhan. Bisa jadi maksudnya sama. 
Selanjutnya, ia mengutip pendapat Ibnu Taimiyah (Karim 2014; 224) sebagai berikut, bahwa naik dan turunnya harga tidak selalu disebabkan oleh tindakan tidak adil dari sebagian orang yang terlibat transaksi. Bisa jadi penyebabnya adalah penawaran yang menurun akibat inefisiensi produksi, penurunan jumlah impor barang-barang yang diminta atau juga tekanan pasar. Karena itu, jika permintaan terhadap barang meningkat, sedangkan penawaran menurun, harga barang tersebut akan naik. Begitu pula sebaliknya. Kelangkaan dan melimpahnya barang mungkin disebabkan oleh tindakan yang adil atau mungkin juga tindakan yang tidak adil.

Menurut Ibnu Taimiyah juga, bahwa penawaran bisa datang dari produksi domestik dan impor. Perubahan dalam penawaran digambarkan sebagai peningkatan atau penurunan dalam jumlah barang yang ditawarkan, sedangkan permintaan sangat ditentukan oleh selera dan pendapatan. Besar kecilnya kenaikan harga bergantung pada besarnya perubahan penawaran dan atau permintaan. Bila seluruh transaksi sudah sesuai aturan, kenaikan harga yang terjadi merupakan kehendak Allah.

Khalifah Umar bin Khathab berkeliling pasar sambil membawa tongkat yang ia pergunakan untuk memukul para pedagang yang tidak mengerti fikih dan mengeluarkannya dari pasar. Ia berkata: tidak boleh berjual-beli di pasar kami (kita) kecuali orang yang telah mendalami agama. (Syahhatah 2002, 18)

Mengenai kebahagiaan (happiness), Antonio berpendapat (Nafik 2009, 22), bahwa perekonomian yang menyeimbangkan aspek dunia dan akhirat merupakan karakteristik unik ekonomi Islam. Perpaduan unsur material dan spiritual ini tidak dijumpai dalam sistem ekonomi lain, baik kapitalis maupun sosialis. Karena itu, kesejahteraan hidup menurut Islam adalah kesejahteraan di dunia tanpa melupakan kebahagiaan hakiki di akhirat.

(Marthon 2004, 27) mengatakan bahwa sistem perekonomian kontemporer hanya konsen terhadap peningkatan utility dan nilai-nilai materialisme suatu barang tanpa menyentuh nilai-nilai spiritualisme dan etika kehidupan masyarakat.

Sistem kapitalisme memisahkan intervensi agama dari berbagai kegiatan dan kebijakan ekonomi, padahal pelaku ekonomi merupakan penggerak utama bagi perkembangan peradaban dan perekonomian masyarakat. Akhirnya kehidupan perekonomian masyarakat terbebas dari koridor agama, sehingga kebijakan individuallah yang berperan dalam pengembangan kehidupan dan kesejahteraan masyarakat. Dengan demikian terciptalah individu-individu yang bersifat individualis, egois, dan materialis.

Dalam konsep Karl Marx, agama merupakan penghambat bagi terciptanya kesejateraan dan pertumbuhan ekonomi masyarakat (an obstacle to economic growth). Sedangkan dalam konsep ekonomi Islam, dialektika antara nilai-nilai spiritualisme dan materialism menjadi perhatian khusus.

Mengenai kebahagiaan secara khusus bagi orang yang berpuasa adalah sebagaimana yang disabdakan oleh Rasulullah SAW, (Zabidi 2008, 365) bahwa: "Terdapat dua kebahagiaan bagi orang yang berpuasa yang dengan keduanya ia merasa bahagia: ketika ia berbuka dan ketika ia berjumpa dengan Tuhannya, maka ia bergembira dengan puasanya itu."

Gross National Happiness (GNH) bisa dipahami sebagai kebahagiaan negara yang tercermin dari kebahagiaan yang dirasakan oleh warga negaranya baik di dalam negeri atau warga negara yang sedang berada di luar negeri (Bahri 
2010). Istilah ini muncul dari praktik sebuah negara kecil di lereng gunung Himalaya, yaitu Bhutan. Bhutan dengan penduduknya 700 ribu jiwa dan dipimpin oleh perdana menteri bernama Jigme Thinley, sang inspirator istilah GNH di atas.

Gross National Happiness (GNH) merupakan produk baru pemikiran manusia yang merasa trauma dengan kegagalan Gross National Product (GNP) yang diusung oleh aliran ekonomi Kapitalis. GNP lebih menitikberatkan pada materi yang dikuasai oleh setiap warga negara dengan mengesampingkan dimensi spiritual yang melekat erat dalam setiap jiwa manusia. Bersebarangan dengan itu, GNH membangun nilai tersendiri bahwa manusia dengan dimensi spiritualnya pada hakikatnya sangat mendambakan kebahagiaan, dan kebahagiaan itu tidak mutlak terletak pada pemilikan materi semata.

Belum tentu dengan banyaknya materi yang dimiliki seseorang akan memberikan kebahagiaan hakiki dalam hidupnya yang serba mewah. Apalagi dalam proses mendapatkan materi atau kekayaan di maksud, dengan banyaknya waktu yang tersita dan pemerasan tenaga yang tidak sedikit dan cukup melelahkan, seseorang belum tentu bisa menikmati hidupnya dengan tenang dan bahagia.

Di zaman yang penuh kompetisi ini, seakan-akan waktu tercipta hanyalah untuk bekerja dan mengejar materi. Akhirnya, setelah kejenuhan tiba dan dirasakan seseorang, maka sangat mungkin ia lepas kendali dengan membuat kehancuran demi kehancuran, termasuk mengakhiri hidupnya secara tragis. Fenomena seperti ini tidak lagi menjadi hal aneh dan asing di tengah hiruk-pikuk dunia saat ini.

GNP hanya berorientasi materi, sedangkan GNH fokus dengan dimensi spiritual. Mungkin banyak yang belum bisa menerima dan belum bisa sepakat dengan argumentasi yang mengatakan bahwa materi bukanlah lambang dari suatu pencapaian kebahagiaan. Itu memang betul! Tapi, materi tentunya tidak selamanya memberi kebahagiaan dan ketenangan bagi pemiliknya. Fenomena bunuh diri yang marak di zaman ini seperti yang terungkap di atas adalah salah satu buktinya.

Tentang Ramadanomic, Istilah ini memang belum begitu populer, palingpaling ia baru dikonsumsi oleh kalangan ekonom, itu pun mungkin masih sebatas ekonom muslim. Jika ditelusuri dari makna tekstualnya, ramadanomics merupakan kombinasi dari dua kata Ramadhan dan ekonomi, bila di-inggriskan menjadi ramadanomics. Yaitu ilmu ekonomi yang mebahas berbagai gejalanya dalam konteks bulan Ramadhan. (Bahri 2011)

Mengenai konsumsi. Secara kasat mata, tidak ada yang membantah bahwa Ramadhan merupakan bulan kesederhanaan. Perilaku ekonomi umat Islam akan jelas tampak lebih sederhana di bulan agung ini. Dengan ritual menahan diri dari makan dan minum, otomatis menghentikan konsumsi makanan dan minuman untuk sementara waktu, dari imsak sampai waktu berbuka. Tapi, yang terjadi di lapangan sangat jauh berbeda dengan teori ini. Sudah menjadi rahasia umum bahwa harga barang dan jasa sudah pasti naik sebelum Ramadhan dan lebaran. Ini mengindikasikan bahwa pola konsumsi umat Islam sebagai aktor utama yang tampil di bulan Ramadhan tidak mengalami penurunan sebagaimana dijelaskan teori di atas, Ramadhan bulan kesederhanaan. 


\section{MASALAH DAN PEMBAHASAN}

Terlepas dari data dan catatan statistik, ekonomi masyarakat Indonesia secara umum cukup dinamis. Hal itu juga terjadi di Kabupaten Bengkalis, secara riil, perekonomian masyarakat dari tahun ke tahun (year on year) menunjukkan tren positif. Sebagai bukti dari dinamika itu adalah bertambahnya aset yang mereka miliki. Hal itu juga tampak dari daya beli dan konsumsi mereka. Jika yang terjadi adalah sebaliknya, sudah tentu merupakan fenomena temporal saja.

Di Negeri Junjungan Bengkalis, limpahan nikmat dan rahmat itu benarbenar terasa. Dengan keimanan dan ketakawan masyarakatnya, kekuatan ekonomi seakan-akan bermula dari sini. Fenomenologi perekonomian di bulan Ramadhan (Ramadanomic) begitu fenomenal di negeri yang terkenal dengan baik hati ini. Limpahan rezeki mengalir secara deras, karena Allah SWT. telah membuka pintu keberkahan langit dan bumi sebagai bentuk balasan atas keimanan dan ketakwaan masyarakatnya. Tinggal lagi, untuk selanjutnya, bagaimana mereka bisa menjaga limpahan rezeki itu ke jalan kebaikan. Sebagai nafkah keluarga dan memenuhi kebutuhan primer misalnya, serta tidak terjerat di jalan yang bathil, seperti mengonsumsi barang atau jasa yang haram serta jauh dari sifat konsumerisme.

Perilaku konsumsi komoditas yang halal, menghindari sifat berlebihlebihan (israf) dan tidak bakhil membelanjakan harta di jalan allah SWT. ( $f i$ sabilillah) semestinya selalu diingat demi selalu menjaga keutuhan kualitas keimanan dan ketakwaan. Dengan sifat dan sikap sederhana pada gilirannya berdampak pada mekanisme pasar yang merupakan variabel tak terpisahkan dalam kehidupan.

Dan, dengan sifat dan sikap sederhana itu juga niscaya akan membuat mekanisme pasar berjalan dengan semestinya, tanpa rekayasa, dan selalu berorientasi pada kepentingan dan kebutuhan masyarakat luas yang notabene sebagai pembeli. Sehingga pasar berjalan sesuai permintaan (demand) dan penawaran (supply), tanpa penipuan (tadlis).

Berbagai usaha ke arah kebaikan, baik ihsan, khairat, ishlah (shalihat), maupun falah pada muaranya akan melahirkan kebahagiaan (happiness) yang hakiki dan sejati. Kebahagiaan yang dimaksud adalah hasanah fid dunya wal akhirah.

\section{PENUTUP}

Limpahan rezeki allah SWT. kepada bumi Indonesia dan khususnya kepada Negeri Junjungan Bengkalis sudah tentu tidak terhitung jumlahnya, terlebih lagi rezeki di bulan Ramadhan. Hanya usaha selalu bersyukurlah yang hanya bisa dikedepankan dan dipanjatkan ke haribaan-Nya.

Meskipun dinamika pasar terlihat bergejolak, namun, dengan selalu bersifat dan bersikap sederhana, niscaya mekanisme pasar berjalan sesuai dengan yang diharapkan.

Sehingga kebahagiaan (happiness) yang menjadi dambaan setiap insan selalu dirasakan oleh masyarakat Negeri Junjungan Bengkalis yang terkenal religius. 


\section{UCAPAN TERIMAKASIH}

Alhamdulillah... syukur kepada Allah SWT. atas segala limpahan nikmat dan hidayah-Nya, sehingga tugas ini dapat diselesaikan meskipun dengan hasil sangat sederhana. Terimakasih juga saya ucapkan kepada Istriku, Rosida binti M. Yunus, Ananda Shifa Dhighthinqizh, Turbah Ardhina, dan Tazakka Muhammad, atas segala dukungan dan kebaikannya.Terimakasih juga saya ucapkan kepada Karib-Kerabat. Dan, tak lupa ucapan terimakasih kepada Sivitas Akademika STIE Syariah Bengkalis atas semua bantuannya dan perhatiannya.

\section{DAFTAR PUSTAKA}

Bahri, Saiful. 2010. Gross National Happiness. Pekanbaru: Riau Pos. 2011. Kesinambungan Ramadanomics. Pekanbaru: Riau Pos.

Chaudry, M. Sharif. 2012. Sistem Ekonomi Islam: Prinsip Dasar. Jakarta: Kencana.

Departemen Agama, RI., Lajnah Pentashih Mushaf al-Qur'an. 1990. Al-Qur'an dan Terjemahannya. Madinah: Mujamma' al-Malik Fahd.

Karim, Adiwarman Azwar. 2014. Ekonomi Mikro Islami cet. VI, ed. V. Jakarta: Rajagrafindo Persada.

Mardani. 2015. Hukum Sistem Ekonomi Islam cet. I. Jakarta: Rajagrafindo Persada.

Marthon, Said Sa'ad, 2004. al-Madkhal li al-Fikri al-Iqtishad fi al-Islam, terjemahan oleh Ahmad Ikhrom dan Dimyauddin, Ekonomi Islam di Tengah Krisis Ekonomi Global cet. I. Jakarta: Zikrul Hakim.

Nafik HR, Muhamad. 2009. Bursa Efek \& Investasi Syariah cet. I. Jakarta: Serambi.

Suhendi, Hendi. 2005. Fiqh Muamalah ed. II. Jakarta: Raja Grafindo Persada.

Syahathah, Husain. 2002. Berbagai Pelanggaran Syari'at Dalam Urusan Keuangan cet. I. Jakarta: Rabbani.

Zabidi, Imam Az. 2008. Ringkasan Shahih Bukhari (Mukhtashar Shahih Bukhari) cet. I. Bandung: Mizan. 